\title{
Interaction of Bephratelloides cubensis (Hymenoptera: Eurytomidae) with Annona macroprophyllata fruits in orchards of Chiapas, Mexico
}

\author{
José Norman González-Sánchez ${ }^{1}$, Alma Rosa González-Esquinca ${ }^{1}$, \\ Claudia Azucena Durán-Ruiz ${ }^{1}$, Iván De-la-Cruz-Chacón ${ }^{1} \&$ Marisol Castro-Moreno ${ }^{1 *}$ \\ 1. Universidad de Ciencias y Artes de Chiapas, Laboratorio de Fisiología y Química Vegetal, Instituto de Ciencias \\ Biológicas, Tuxtla Gutiérrez, Chiapas,29000, Mexico; norman.11@hotmail.es, aesquinca@unicach.mx, \\ claudia.duran.ex@unicach.mx, ivan.cruz@unicach.mx, marisol.castro@unicach.mx (*Correspondencia).
}

Received 11-IX-2020. Corrected 09-XII-2020. Accepted 17-XII-2020.

\begin{abstract}
Introduction: Annona macroprophyllata Donn. Smith. (Annonaceae) (syn. Annona diversifolia Saff.) is a valued fruit tree species known as papausa. In Mexico and Central America, this fruit has become an important crop because of its tasty flavor and high pulp content. Its fruits are frequently damaged by the incidence of wasps of the genus Bephratelloides Girault (Hymenoptera: Eurytomidae), which develop inside the seeds. Objective: to report the interaction of Bephratelloides cubensis Ashmead during its life cycle in fruits of A. macroprophyllata. Methods: We periodically collected fruits in different states of growth recording a) oviposition, b) the moment of evident infection, c) the development of the wasps inside the seeds, and d) their emergence as adults. We also determined the proportion of damaged fruits and seeds. Results: The data indicate that wasps preferred to oviposit on fruits with a diameter of less than $8 \mathrm{~cm}$, oviposition was more frequent between 11:00 am and 03:00 pm., and there was $26 \%$ infestation of fruits, and 9\% of seeds. Conclusion: It is an obligatory interaction for the wasp, the highest proportion of attack on fruits was in the early stages of fruit development and control actions should focus on the protection of these early stages.
\end{abstract}

Key words: larvae; pupae; adults; plant-insect interactions; pest of Annonaceae.

González-Sánchez, J.N., González-Esquinca, A.R., Durán-Ruiz, C.A., De-la-CruzChacón, I., \& Castro-Moreno, M. (2021). Interaction of Bephratelloides cubensis (Hymenoptera: Eurytomidae) with Annona macroprophyllata fruits in orchards of Chiapas, Mexico. Revista de Biología Tropical, 69(1), 369-378. DOI 10.15517/rbt. v69i1.43827

The family Annonaceae is made up of 128 genera and 2400 recognized species (Chatrou et al., 2012). The genus Annona stands out among them with 166 species (Chatrou et al., 2012; Rainer, 2006). There are around 60 species in Mexico, some of them are important because of their fruits, such as the soursop (Annona muricata), the sugar-apple (A. squamosa), ilama or papausa (A. macroprophyllata) and the cherimoya (A. cherimola) (De-la-Cruz-Chacón, Castro-Moreno, Luna-Cázares, \& GonzálezEsquinca, 2016). Annona macroprophyllata
(Annona diversifolia) is a Mexican and Central America native fruit which has become an important crop because of its tasty flavor, high pulp content, nutritional value and antioxidant properties (Julian-Loaeza, Sántos-Sánchez, Valadez-Blanco, Sánchez-Guzmán, \& SalasCoronado, 2011).

There are more than 296 species of arthropods interacting with different Annonaceae, but the knowledge of the biology and habits of these species is scarce. Some groups of insects that are reported as pests belong to 
the families Coccidae (Hemiptera), Noctuidae, Oecophoridae (Lepidoptera), Nitidulidae (Coleoptera) and Eurytomidae (Hymenoptera) (Peña \& Bennett, 1995).

Bephratelloides Girault (Hymenoptera: Eurytomidae) is a genus composed of seven species of stingless wasps that are associated with Annonaceae because five of those species complete part of their life cycle inside the seeds of these plants (Grissell \& Foster, 1996; Noyes, 2019). In particular, Bephratelloides pomorum Fabricius and B. cubensis Ashmead are among the most important pests of the commercial species of Annona because of the damage they cause to the fruits (Grissell \& Schauff, 1990; Peña \& Bennett, 1995; Castañeda-Vildózola, Nava-Díaz, Franco-Mora, Lomeli-Flores, \& Peña, 2011; Silva, Broglio, Lemos, Salvador, $\&$ Neves, 2014). There are also reports of their presence in other genera of the Annonaceae like Cymbopetalum (Grissell \& Foster, 1996).

Bephratelloides cubensis begins its life cycle when the females oviposit inside the seeds of fruits in early phenological stages (Nadel \& Peña, 1991). Females lay one egg per seed and these require approximately two or three weeks to hatch (Brunner \& Acuña, 1967; Castañeda-Vildózola et al., 2010; HernándezFuentes, Urias-López, \& Bautista-Martínez, 2010). The larvae that hatch feed on the endosperm, and after three to six weeks these larvae transform into pupae and later the adult wasps exit from holes, they chew through the seed and fruit, to finally mate and begin a new cycle (Castañeda-Vildózola et al., 2010; HernándezFuentes et al., 2010; Durán-Ruiz et al., 2019; Nadel \& Peña, 1991).

The Annona macroprophyllata market is still local; however, it's delicious flavor and biotechnological use give it potentially wider market. That means that $A$. macroprophyllata is a potential fruit crop, important because it is a source of possible bioactive compounds (González-Esquinca, De-la-Cruz-Chacón, Castro-Moreno, Orozco-Castillo, \& Riley-Saldaña, 2014). In Chiapas A. macroprophyllata is a tree of incipient cultivation, increasingly rare in the wild, it is cultivated in backyards and as living fences, or it inhabit areas of Deciduous and Semideciduous Dry Forests (GonzálezEsquinca, De-la-Cruz-Chacón, Castro-Moreno, \& Riley-Saldaña, 2016). Studies like those of Castañeda-Vildózola et al. (2010) and DuránRuiz et al. (2019) allow for the detection of $B$. cubensis parasitizing A. macroprophyllata. Studies indicate that the main damages to $A$. macroprophyllata crops are the exit holes from the seed which allow the development of fungi such as Colletotrichum sp. provoking anthracnose disease and therefore a loss in harvest (Nadel \& Peña, 1991; Peña \& Bennett, 1995; Cruz \& Deras, 2000; Castañeda-Vildózola et al., 2010; Hernández-Fuentes et al., 2010).

This study characterizes the attack process of Bephratelloides cubensis and its life cycle during the fructification of A. macroprophyllata in backyard crops. Our hypothesis is that wasps damage a low proportion (less than 50 $\%)$ of the fruits when trees are cultivated in backyards, where their density is lower than in places of intensive commercial cultivation. In order to test this hypothesis, we collected fruits, made observations throughout the season of fruit development, and related that information to the development of the wasps.

\section{MATERIALS AND METHODS}

Study site: We conducted the fieldwork in the community of Nuevo Carmen Tonapac, in the municipality of Chiapa de Corzo, Chiapas, Mexico, which is located in the Central Depression of Chiapas (16 $41^{\prime} 48^{\prime \prime}$ W \& 92 $57^{\prime} 20^{\prime \prime}$ $\mathrm{N})$. The original vegetation in this place corresponds to Deciduous Dry Forest, with ecotone of Semideciduous Medium Dry Forest. The fieldwork was carried out from July to August 2014.

Tree selection: We randomly selected 50 of the 70 adult trees counted in the community. On each tree, we marked 5 fruits of 4-5 $\mathrm{cm}$ diameter. We visited the trees every 15 days during two consecutive months (which is the mean duration of the development of the fruits) and collected one of the five fruits from 
each tree (50 fruits each time). The fruits were placed in a portable cooler and transferred to the Laboratorio de Fisiología y Química Vegetal of UNICACH. The fruits were collected in five stages of development: a) initial harvest or first stage of development (day 0), second harvest or stage (day 15), third harvest or stage (day 30), fourth harvest or stage (day 45), and fifth harvest or stage (day 60).

Measurement of fruits and seeds and monitoring of larvae, pupae and adults: At the moment of collecting fruits, we measured their length and width with a measuring tape. We also measured the seeds with a caliper. We opened the seeds longitudinally. The larvae, pupae and adults of $B$. cubensis were preserved in a $70 \%$ alcohol solution. In all the five stage of fruit development, we quantified the damaged fruits and the infested seeds.

The identification was carried out in the Colección Nacional de Insectos of the Instituto de Biología of the Universidad Nacional Autónoma de México (IB-UNAM), following the taxonomic keys of Grissell \& Schauff (1990) and Grissell \& Foster (1996). Observations were made on a Carl Zeiss stereoscope microscope.

Larval instar determination: Mandibles were isolated from the soft body with a $10 \%$ potassium hydroxide solution for 24 hours and preserved in glycerin for microscopic observation, mandibles were observed on a ZEISS ${ }^{\circledR}$ Primo Star optic microscope. We determined the larval instars comparing the progressive development of the mandibles, considering the development of the teeth, condyle and tip. This method was modified from Hernández-Fuentes et al. (2010) and used in Durán-Ruiz et al. (2019) avoiding the use of the mandible size due to its heterogeneity.

Statistical analysis: We tested the differences in the morphometry of seeds and fruits with a one-way analysis of variance and a post-hoc least significant difference test (LSD). To characterize the fruit morphometric measurements, their apparent damage and the ratio of females to males, we performed a nonparametric analysis Kruskal-Wallis (KW) and the post-hoc Dwas-Steel-Crichtlow-Fligner (DSCF) tests. To compare the final sizes of the seeds with and without damage caused by the insect, we carried out a student t-test. To determine the relationships between fruit and insect development we carried out polynomial regressions. In all cases, we used the statistical program PAST3.26 (Hammer, Harper, \& Ryan, 2001) and the free version of the program Jamovi to perform the KW and the DSCF tests.

\section{RESULTS}

Development of fruits and seeds: Fruits had an ovoid shape, and a thick, coriaceous and green exocarp (Fig. 1A, Fig. 1B, Fig. 2A). The fruits reached their final size after 45 days and ripen after approximately 60 days $(\mathrm{F}=2041$, $\mathrm{P}=0.0001)$. The seeds of the unripe fruits of the first stage, were small, white translucent (Fig. 2C), with an oily (to the touch), white endosperm and a soft seed coat. Seeds grew constantly until 30 to 45 days, and then they acquired their final characteristics: Dark brown seed coat (dark brown 3/3 in the scale of the Munsell colors chart 2009), with a crustaceous texture and with a size four times larger than the initial stage $(\mathrm{F}=8.4, \mathrm{P}=0.0001)$ (Fig. $1 \mathrm{G}$, Fig. 2B). All the infected and healthy seeds had on average, the same characteristics of size and color $(\mathrm{F}=6.7, \mathrm{P}=0.7)$.

Infected fruits by sample collection: Most of the damaged fruits were detected in the last three stages $(\sim 50 \%)$ while damage was significantly less in the first two $\left(\mathrm{H}^{\prime}=3.9, \mathrm{P}=\right.$ 0.001) (Fig. 2D). Of the 250 collected fruits, 86 were damaged by B. cubensis $(26 \%)$ and of the 3011 seeds, $9 \%$ were infected ( $4 \%$ with some larval instar, $4 \%$ with pupae, and $1 \%$ with adults). The developmental stage of the fruits was associated with the developmental phase of the insects $(\mathrm{r}=0.97$ Legth, $0.87 \mathrm{p}$, 0.68 Width, $\mathrm{P}=0.001$ ) (Fig. 2C). 

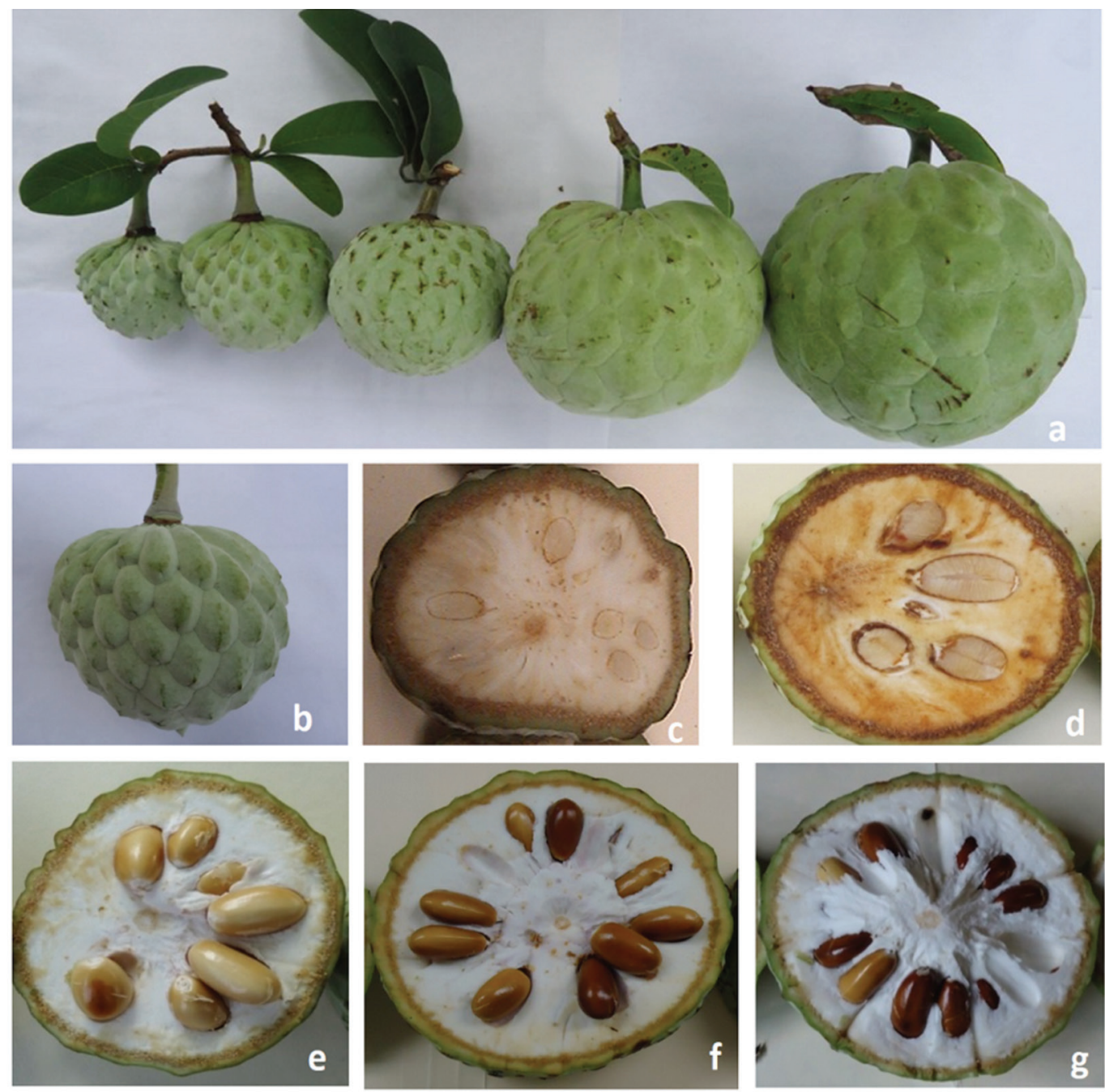

Fig. 1. Fruits in development. A. all stages of development, B-C. First stage (initial harvest, day 0), D. Second stage of development (day 15), E. Third stage (day 30), F. Fourth stage (day 45), G. Fifth stage (day 60).

The external appearance of the unripe seeds infected with larvae in the first instar was similar to the healthy seeds. Both infected and healthy seeds had the same color (dark brown $3 / 3$ according to the Munsell color scale 2009) and did not show visible perforations in the seed coat. However, when dissected, active larvae were found, and the endosperm was partially destroyed by feeding activity (Fig. 3B, Fig. 3C).

The most developed seeds with larvae or pupae inside showed subtle signs of the presence of insects, such as changes in the color of the seed coat (from dark to light brown) and low resistance to compression. Seeds with adult wasps ready to leave and seeds where the wasps already left had an exit pit parallel and opposite to the micropyle (Fig. 3K).

Inside the seeds, we observed the initial and late phases of the larvae, pupae and adults. Still, the frequency of each collection varied. For instance, in the first stage, when fruits were $4.8 \pm 0.5 \mathrm{~cm}$ diameter, we did not find any eggs or larvae (Fig. 3A); in the second 

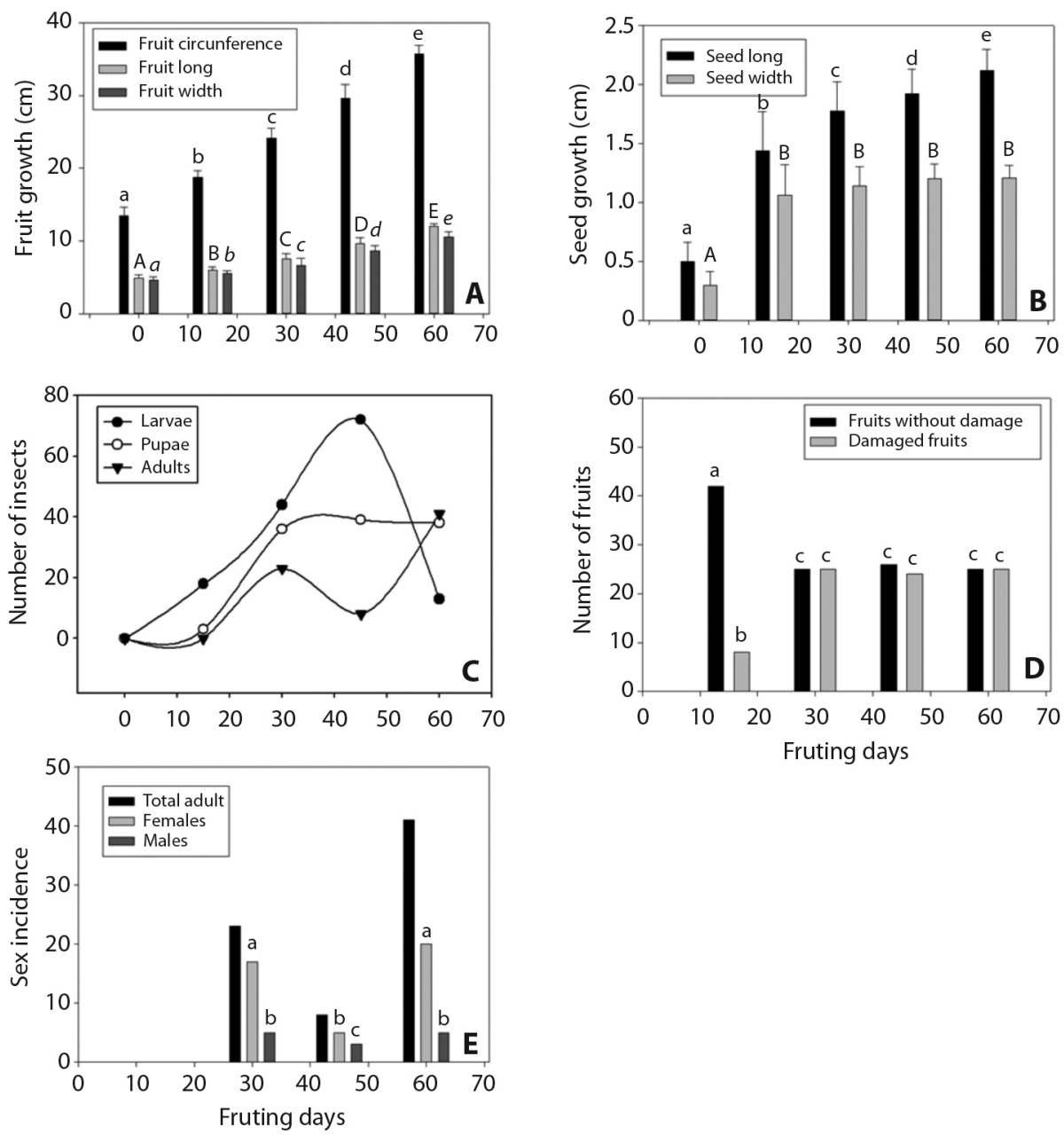

Fig. 2. Fruit and seed growth and development of the life cycle of Bephratelloides cubensis in Annona macroprophyllata seeds during the fruiting season. A. Fruit growth, B. Seed growth, C. Number of pupae and adult larvae during fruiting, D. Fruits damaged or with insects inside the seeds, E. Incidence of sexes of the adult stage. The different letters on the bars in A., B., D. and E. indicate significant differences $\mathrm{p}=0.001$, in $\mathrm{c})$ the frequency of larvae, pupae and adults $(\mathrm{r}=0.97, \mathrm{P}=$ $0.001)$, pupae $(\mathrm{r}=0.87, \mathrm{P}=0.001)$ and adults $(\mathrm{r}=0.68, \mathrm{P}=0.0001)$.

stage, we found fewer larvae and pupae than in the third and fourth collections, but as the size of the fruits increased both, larvae and pupae increased in number. We observed the firsts adults in the third stage $(\mathrm{H}=31.75657 .6$, $\mathrm{P}=0.001$ ) (Fig. 3B). When the fruits reached their final stage of development (fifth stage) the number of larvae decreased significantly, while the number of pupae remained stable and the number of adults increased $(\mathrm{H}=32.443, \mathrm{P}=$ 0.001). It is interesting to note that in the three stages there were more females than males $(\mathrm{H}$ $=43.72, \mathrm{P}=0.001)$.

\section{DISCUSSION}

Bephratelloides cubensis has been reported as a frequent parasite in Annona muricata, $A$. reticulata, $A$. squamosa, $A$. reticulata, $A$. cherimola, A. glabra, A. montana and A. bullata. This wasp completes almost its entire life cycle inside the seeds and is free-living only 

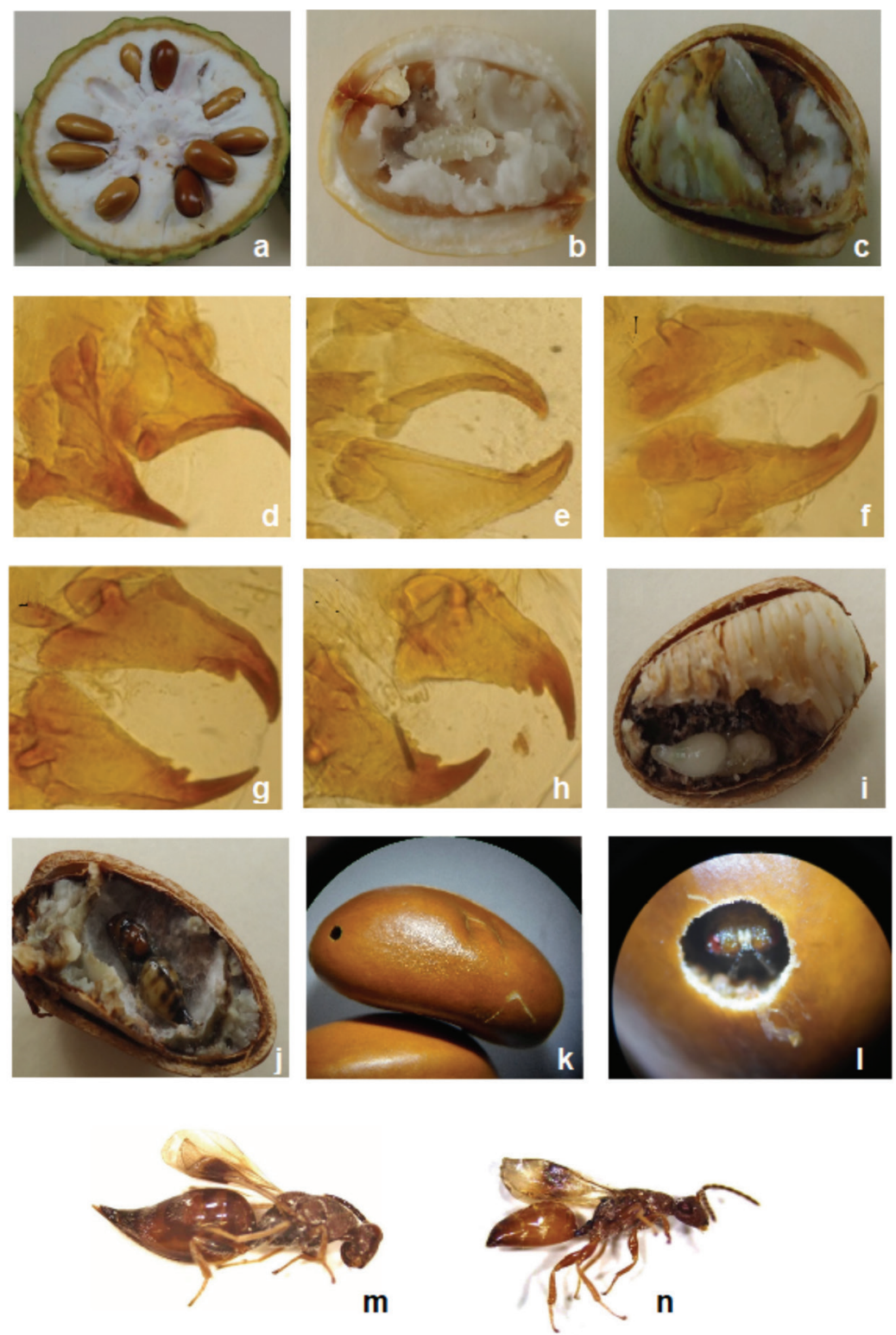

Fig. 3. Development of B. cubensis in the seeds of A. macroprophyllata. A. Seed arrangement in the fruit, B. early larva, C. developed larva, D-H. jaws of the larvae of the five instar, I. early pupa, J. late pupa, K. exit hole of the seeds, L. adult inside the seed, M. adult female, N. adult male.

as adults (Grissell \& Schauf, 1990; CastañedaVildózola et al., 2010; Hernández-Fuentes et al., 2010; Cham et al., 2019). The presence of B. cubensis in A. macroprophyllata has been reported in some areas of Guerrero and Morelos (Castañeda-Vildózola et al., 2010), but in
Chiapas there is only one formal report (DuránRuiz et al., 2019).

The development of B. cubensis was simultaneous with that of fruits and seeds of A. macroprophyllata. Similar to Durán-Ruiz et al. (2019), the growth and accumulation of 
reserve material in the endosperm did not stop even if the larvae fed on the endosperm. The morphometry, and the external appearance of the infested and the healthy seeds were statistically similar during the immature stages of the insect (larvae and pupae). But, the biomass of the damaged seeds decreased by up to $50 \%$ due to the active feeding of the larvae. With the emergence of the adult wasps, the seed coat also presented an exit hole, which differentiated the infested from the healthy seeds. Therefore, this hole is associated with the damage perceived on the surface of the fruit. The fruits attacked by B. cubensis differed from the healthy fruits only when the exit holes from the seed to the exocarp were observed. Thus, the number of holes in the fruit is a physiologic and agronomic indication of the degree of infestation and/or damage caused.

The lack of apparent damage in the early stages of development suggests that wasps oviposit directly inside the immature seeds when the seed coat is still soft and not directly in the pulp, as described by Evangelista, Llanos, \& Valdés (1999). We detected larvae in second stage fruits, and their number increased in the third stage, the highest incidence was in the fourth stage fruits, with and an important decrease in the final stage. In A. muricata, Hernández-Fuentes et al. (2010), reported that females oviposit in fruits with a minimal diameter of $3.1 \mathrm{~cm}$, and a maximum of $7.6 \mathrm{~cm}$. Peña, Glenn, \& Baranowski (1984) mention that the lack of fruit availability forces females of $B$. cubensis to oviposit in fruits of any size even when preferring seeds in development.

We did not observe eggs in any seeds, perhaps due to their resemblance to the seminal endosperm and their small size $(0.1 \mathrm{~mm}$ diameter) (Hernández-Fuentes et al., 2010). In the first fruiting stage ( $4 \mathrm{~cm}$ diameter), we did not detect nor larvae any pupae, probably because only eggs were present which can have an incubation period of up to 24 days according to Hernández-Fuentes et al. (2010). We began to find larvae and pupae of $B$. cubensis in the seeds in the second stage and they increased significantly in the following stage, in all cases there was only one individual per seed.

The larvae in 2nd, 3rd and 4th stage fruits, belonged to all the larval instars, while in the fifth stage, we only found the two last instars, indicating they were ready to pupate. The simultaneous presence of larvae at different instars, even in the same fruit, can be attributed to the quality and the quantity of food inside the seeds and to the oviposition time (Hernández-Fuentes et al., 2010). Barbosa, dos Anjos, \& Picanço (1997) also suggested that the overlapping instars in the same fruit is attributed to the different nutritional potential of each seed.

Pupae were found from the third stage onward, which indicates that larvae require more than 15 days to pupate, this time corresponds to the estimated by Hernández-Fuentes et al, (2010). In that development stage (3th), we found translucent white pupae (less mature) and brown pupae (before entering the adult stage). In the three last stages, we found adult wasps, but when fruits achieved their final size we found adults, larvae and pupae, the latter being in the highest proportion. These data indicate that there is partial synchrony between the phenological stages of fruits, seeds, and wasps. It is noteworthy that the exit hole was presented in all cases in the opposite position to the micropyle, which could indicate that the embryo of the seed could be intact due to its small size $(1 \mathrm{~mm})$.

This plant-animal interaction is coordinated phenologically and is an obligatory relationship for the wasp since most of its life cycle (egg through pupae) occurs inside the seed, and only the adult stage in wasps occurs in free-life (Hernández-Fuentes et al., 2010; Durán-Ruiz et al., 2019). Durán-Ruiz et al. (2019), observed a high synchronization between the life cycle of the insect and the stages of fruit development. Other studies have found a high dependence of the genus Bephratelloides on the species of Annonaceae, which could indicate a possible coevolutionary process. This interaction has been widely described in cultivated Annonaceae and less frequently in wild Annonaceae. Some of the attacked species in Annonaceae 
are A. muricata, A. reticulata, A. squamosa (Castañeda-Vildózola et al., 2010), and Cymbopetalum mayanum (Grissel \& Foster, 1996). Castañeda-Vildózola et al. (2011) present the only report of a species of Bephratelloides developing in another plant family B. ablusus in Diospyros digyna (Ebenaceae) seeds.

Several studies have reported 60 to $100 \%$ of fruits attacked in intensive and semi-intensive tree crops of A. muricata, with harvest losses of 25 to $70 \%$ (Castañeda-Vildózola et al., 2010; Hernández-Fuentes et al., 2010). In Nuevo Carmen Tonapac, Chiapas, A. macroprophyllata is cultivated in backyards, so it is not considered an intensive crop. In this study, we report damages of $26 \%$ in the sampled fruits and $9 \%$ in seeds.

The serious problems caused by $B$. cubensis in soursops and its low incidence in $A$. macroprophyllata can have multiple explanations, perhaps the most important being habitat management in the intensive crops where the species diversity that could control the pest has decreased significantly (Schowalter, 1986). A. muricata is a plant from the Antilles that has been domesticated to ameliorate the organoleptic quality of the fruit but at the expense of other attributes (including phytochemicals) that lead to low genetic variation which is reflected in lower resistance to pests (Shelef, Weisberg, \& Provenza, 2017). In contrast, according to Provenza, Meuret, \& Gregorini (2015) native crops, such as A. macroprophyllata (which is native to Chiapas) have higher genetic diversity compared with $A$. muricata, which gives them more possibilities of adaptation to pests.

In the study site, there are no extensive crops of A. macroprophyllata, and even when the incidence of $B$. cubensis is low (26\%), the quality of the fruits is affected when the wasps emerge from the exit holes in the seeds. The attack of the insect occurs in a higher proportion of fruits at their early stages, demonstrating that actions to control populations of $B$. cubensis should focus on the early stages of fruit development when proposing crops of Annonaceae in the area.
Ethical statement: authors declare that they all agree with this publication and made significant contributions; that there is no conflict of interest of any kind; and that we followed all pertinent ethical and legal procedures and requirements. All financial sources are fully and clearly stated in the acknowledgements section. A signed document has been filed in the journal archives.

\section{ACKNOWLEDGMENTS}

We are indebted to the inhabitants of Nuevo Carmen Tonapac, Chiapas, who allowed the early samples collection of fruits for this study. We thank Dr. Alejandro Zaldivar Riverón from the Colección Nacional de Insectos IB-UNAM, for his help with the identification of the organisms.

\section{RESUMEN}

Interacción de Bephratelloides cubensis (Hymenoptera: Eurytomidae) con frutos de Annona macroprophyllata en huertos de Chiapas, México. Introducción: Annona macroprophyllata Donn. Smith. (Annonaceae) es una especie de árbol frutal, conocida como papausa. En México y América Central, esta fruta se ha convertido en un cultivo importante y valorado debido a su delicioso sabor y la cremosa textura de su pulpa. Sus frutos son frecuentemente dañados por la incidencia de avispas del género Bephratelloides Girault (Hymenoptera: Eurytomidae), que se desarrollan dentro de las semillas. Objetivo: describir la interacción de Bephratelloides cubensis Ashmead durante su ciclo de vida en frutos de A. macroprophyllata. Método: Recolectamos frutos en diferentes estados de crecimiento registrando a) la ovoposición, b) el momento de la infección evidente, c) el desarrollo de las avispas dentro de las semillas, y d) su emergencia como adultos. También determinamos la proporción de frutas y semillas dañadas. Resultados: Los datos indican que las avispas preferían ovipositar en frutas con un diámetro de menos de $8 \mathrm{~cm}$, la oviposición era más frecuente entre las 11:00 a.m. y las 3:00 p.m., y que había un $26 \%$ de la infestación en las frutas y un $9 \%$ en semillas. Conclusión: Es una interacción obligada para la avispa y la mayor proporción de ataque a los frutos fue en las etapas tempranas de desarrollo de frutos y las acciones de control se deberían enfocar a la protección de estas etapas.

Palabras clave: larvas; pupas, avispas adultas; interacciones planta-insecto; plaga de Annonaceae. 


\section{REFERENCES}

Barbosa, M.J., dos Anjos, N., \& Picanço, M. (1997). Ciclo biológico del barrenador de semilla de Guanábana (Hymenoptera: Eurytomidae). Agronomía Tropical, 47(4), 507-519. DOI: 10.1590/ S1519-566X2010000400010

Brunner, S.C., \& Acuña, J. (1967). Sobre la biologia de Bephrata cubensis Ashm., el insecto perforador de las frutas annonaceas. Academia de Ciencias de Cuba Instituto de Agronomía, 1, 1-14

Castañeda-Vildózola, A., Nava-Díaz, C., Váldez-Carrasco, J., Ruiz-Montiel, C., Vidal-Hernández, L., \& BarriosMatias, S. (2010). Distribution and host range of Bephratelloides cubensis Ashmead (Hymenoptera: Eurytomidae) in Mexico. Neotropical Entomology, 39(6), 1053-1055

Castañeda-Vildózola, A., Nava-Díaz, C., Franco-Mora, O., Lomeli-Flores, J.R., \& Peña, J.E. (2011). Diospyros digyna (Ebenaceae): a new host record for Bephratelloides ablusus (Hymenoptera: Eurytomidae) in Mexico. Florida Entomologist, 94(4), 1071-1072.

Cham, A.K., Luna-Esquivel, G., Robles-Bermúdez, A., Ríos-Velasco, C., Coronado-Blanco, J.M., \& Cambero-Campos, O.J. (2019). Insects associated with the soursop (Annona muricata L.) crop in Nayarit, Mexico. Florida Entomologist, 102(2), 359-365.

Chatrou, L.W., Pirie, M.D., Erkens, R.H., Couvreur, T.L., Neubig, K.M., Abbott, J.R., \& Chase, M.W. (2012). A new subfamilial and tribal classification of the pantropical flowering plant family Annonaceae informed by molecular phylogenetics. Botanical Journal of the Linnean Society, 169(1), 5-40.

Cruz, E., \& Deras, H. (2000). Colecta y establecimiento de anonáceas en El Salvador. Agronomía Mesoamericana, 11(2), 91-95.

De-la-Cruz-Chacón, I., Castro-Moreno M., Luna Cázares, L.M., \& González-Esquinca, A.R. (2016). La familia Annonaceae Juss. Lacandonia, 10(2), 73-85.

Durán-Ruiz, C.A., Cruz-Ortega, R., Zaldívar-Riverón, A., Zavaleta-Mancera, H.A., De-la-Cruz-Chacón, I., \& González-Esquinca, A.R. (2019). Ontogenic synchronization of Bephratelloides cubensis, Annona macroprophyllata seeds and acetogenins from Annonaceae. Journal of Plant Research, 132(1), 81-91.

Evangelista, L.S., Llanos, L.A., \& Valdés, E.M.E. (1999). Descripción morfológica de Bephratelloides cubensis (Hymenoptera: Eurytomidae). In Memorias del Segundo Congreso Internacional de Anonáceas (pp. 204-208). Chiapas, México: UNICACH.

González-Esquinca, A.R., De-La-Cruz-Chacón, I., Castro-Moreno, M., Orozco-Castillo, J.A., \& RileySaldaña, C.A. (2014). Alkaloids and acetogenins in
Annonaceae development: biological considerations. Revista Brasileira de Fruticultura, 36(1), 01-16.

González-Esquinca, A.R., De-la-Cruz-Chacón, I., CastroMoreno, M., \& Riley-Saldaña, C.A. (2016). Phenological strategies of Annona from deciduous forest of Chiapas, Mexico. Botanical Sciences, 94(3), 531-541.

Grissell, E.E., \& Foster, M.S. (1996). A new Bephratelloides (Hymenoptera: Eurytomidae) from seeds of Cymbopetalum (Annonaceae) in Mexico. Proceedings of the Entomological Society of Washington, 98(2), 256-263.

Grissell, E.E., \& Schauff, M.E. (1990). A synopsis of the seed-feeding genus Bephratelloides (Chalcidoidea: Eurytomidae). Proceedings of the Entomological Society of Washington, 92(2), 177-187.

Hammer, Ø. Harper, D.A.T, \& Ryan, P.D. (2001). PAST: Paleontological statistics software package for education and data analysis. Palaeontologia Electronica, 4(1), 9. Retrieved from: http://palaeo-electronica. org/2001_1/past/issue1_01.htm

Hernández-Fuentes, L.M., Urias-López, M.A., \& BautistaMartínez, N. (2010). Biology and behavior of the seed borer wasp Bephratelloides cubensis Ashmead (Hymenoptera: Eurytomidae). Neotropical Entomology, 39(4), 527-534.

Julián-Loaeza, A.P., Santos-Sánchez, N.F., Valadez-Blanco, R., Sánchez-Guzmán, B.S., \& Salas-Coronado, R. (2011). Chemical composition, color, and antioxidant activity of three varieties of Annona diversifolia Safford fruits. Industrial Crops and Products, 34(2), $1262-1268$

Nadel, H., \& Peña, J. E. (1991). Seasonal oviposition and emergence activity of Bephratelloides cubensis (Hymenoptera: Eurytomidae), a pest of Annona species in Florida. Environmental entomology, 20(4), 1053-1057.

Noyes, J.S. (2019). Universal Chalcidoidea Database. Retrieved from http://www.nhm.ac.uk/chalcidoids

Peña, J.E., \& Bennett, F.D. (1995). Arthropods associated with Annona spp. in the Neotropics. Florida Entomologist, 78(2), 329-349. DOI: 10.2307/3495906

Peña, J.E., Glenn, H., \& Baranowski, R.M. (1984). Important insect pests of Annona spp. in Florida. Proceedings of the Florida State Horticulture Society, 97, 337-340.

Provenza, F.D., Meuret, M., \& Gregorini, P. (2015). Our landscapes, our livestock, ourselves: restoring broken linkages among plants, herbivores, and humans with diets that nourish and satiate. Appetite, 95, 500-519.

Rainer, H. (2006). Monographic studies in the genus Annona L.(Annonaceae): Inclusion of the genus Rollinia 
A. ST.-HIL. Annalen des Naturhistorischen Museums in Wien für Botanik und Zoologie, 20(4) 191-205.

Schowalter, T.D. (1986). Ecological strategies of forest insects: the need for a community-level approach to reforestation. New Forests, 1(1), 57-66.

Shelef, O., Weisberg, P.J., \& Provenza, F.D. (2017). The value of native plants and local production in an era of global agriculture. Frontiers in Plant Science, 8 , 2069. DOI: $10.3389 /$ fpls.2017.02069.

Silva, L.S.D, Broglio, S.M.F., Lemos, E.E.P., Salvador, T.D.L., \& Neves, M.D.S. (2014). Control of Cerconota anonella (Sepp.) (Lep: Oecophoridae) and Bephratelloides pomorum (Fab.) (Hym.: Eurytomidae) in sugar apple (Annona squamosa L.). Revista Brasileira de Fruticultura, 36, 305-309. 